\title{
Pola Komunikasi Antarbudaya Mertua dan Menantu Beda Etnis
}

\author{
Stefanny Cristina M.S, Ahmad Junaidi \\ Stefannycristinaa@gmail.com, alexjunaidi@gmail.com \\ Universitas Tarumanagara, Jakarta
}

\begin{abstract}
Researchers want to find out how the communication patterns that exist between parents inlaws and son or daughter in-laws who had different ethnic backgrounds. Communication in a family is an important aspect in terms of establishing good relations between families and building harmonious relationships, especially in couples in-laws. Communication that exists between the three couples parents in law and son or daughter in-laws who had different ethnic backgrounds. The researcher also wanted to find out what barriers to intercultural communication the three couple parents-in-law and son or daughter-in-law went through. The method used by the researchers in this research was a descriptive qualitative research method using in-depth interview by three couple parents in-laws and son or daughter in-law and also a literature study. After conducting research on three couple parents in law and son or daughter in-law, the three couples have gone through a long communication process, and the communication patterns established between the three couples are not different, all three had a transactional communication model, because the three parents-in-law and son or daughterin-law are both recipients and the sender of the message in a continuous and responsible for the impact and effectiveness of the communication that occurs. barriers in intercultural communication experienced by these three couple parents-in-law and son or daughter-in-law, based on the Nine barriers of intercultural communication presented by Chaney \& Martin (2004). The nine obstacles were not experienced by the three couple parents-in-law and the son or daughter in-law.
\end{abstract}

Keywords: barriers, communication, parents in law, patterns, son or daughter in law.

\begin{abstract}
Abstrak
Peneliti ingin mengetahui bagaimana pola komunikasi yang terjalin antara mertua dan menantu yang berbeda latar belakang etnis. Komunikasi dalam sebuah keluarga merupakan aspek penting dalam hal menjalin hubungan baik antar keluarga dan membangun hubungan yang harmonis terutama pada pasangan menantu dan mertua. Komunikasi yang terjalin antara ketiga pasangan menantu dan mertua ini memiliki latar belakang etnis yang berbeda. Peneliti juga ingin mengetahui apa saja hambatan komunikasi antarbudaya yang dilalui ketiga pasangan mertua dan menantu tersebut Metode yang digunakan peneliti dalam penelitian ini adalah metode penelitian deskriptif kualitatif dengan menggunakan teknik pengumpulan data wawancara mendalam dengan tiga pasangan menantu dan mertua dan juga studi kepustakaan. Setelah melakukan penelitian kepada tiga pasangan menantu dan mertua, ketiga pasangan tersebut telah melalui proses komunikasi yang panjang, dan pola komunikasi yang terjalin antara ketiga pasangan tersebut tidak berbeda, ketiganya memiliki model komunikasi transaksional, karena ketiga pasangan mertua dan menantu tersebut sama-sama menjadi penerima dan pengirim pesan dalam waktu yang berkelanjutan dan bertanggung jawab terhadap dampak dan efektivitas komunikasi yang terjadi. Hambatan komunikasi antarbudaya yang dialami ketiga pasangan mertua dan menantu ini, berdasarkan Sembilan hambatan komunikasi antarbudaya yang dipaparkan oleh Chaney \& Martin (2004). Sembilan hambatan tersebut tidak dialami oleh ketiga pasangan mertua dan menantu tersebut.
\end{abstract}

Kata Kunci: hambatan, komunikasi, mertua, menantu, pola. 


\section{Pendahuluan}

Hal yang mendasar pada kehidupan manusia merupakan komunikasi, komunikasi menjadi fenomena dalam terbentuknya suatu komunitas atau masyarakat yang diintegrasi oleh informasi dimana setiap individu di dalamnya saling berbagi informasi agar mencapai tujuan bersama (Rohim, 2016). Komunikasi menurut Ruben dan Steward (Ngalimun, 2017) adalah proses dimana individu - individu terlibat dalam sebuah hubungan, kelompok, organisasi dan masyarakat yang memberi respon, dan menciptakan pesan agar dapat beradaptasi. Beberapa pakar di bidang komunikasi telah mengklasifikasikan komunikasi berdasarkan konteksnya, biasanya indikator yang digunakan adalah jumlah peserta yang terlibat dalam komunikasi salah satunya komunikasi antarpribadi.

A. Devito (Edi dan Syarwani, 2016) menyatakan pengertian komunikasi antarpribadi adalah proses penerimaan dan pengiriman pesan di antara dua individu atau antara kelompok kecil, dengan efek dan umpan balik seketika. Komunikasi antarpribadi dapat terjadi kapan saja, dengan siapa, dan dimana saja, salah satu fenomena komunikasi antarpribadi adalah komunikasi dalam hubungan keluarga.

Rae Sedwig (Sanadi, 2016) mendefinisikan komunikasi keluarga sebagai sebuah pengorganisasian dengan memakai kata-kata, intonasi suara, bahasa tubuh, tindakan untuk menciptakan sebuah harapan serta ungkapan perasaan dan saling memberi pengertian. Galvin \& Brommel (Budyatna dan Ganiem, 2011) mengartikan sebuah keluarga sebagai sebuah kelompok dimana manusia memiliki hubungan yang akrab dan menumbuhkan rasa berumah tangga dan identitas kelompok, disertai dengan ikatan yang erat perihal kesetiaan serta emosi, dan juga mengalami sejarah dan menatap masa depan.

Budaya berperan penting dalam bagaimana manusia mengamati dan berkomunikasi dengan realita. Charley H. Dood (Ridwan, 2016) mengungkapkan komunikasi antarbudaya meliputi komunikasi yang melibatkan peserta komunikasi yang mewakili pribadi, antarpribadi, atau kelompok dengan tekanan pada perbedaan latar belakang kebudayaan yang mempengaruhi perilaku komunikasi para peserta. Dalam kehidupan keluarga pernikahan beda etnis hal tersebut tentunya terkadang muncul hambatan komunikasi antar budaya. Komunikasi antar etnik atau antar ras menurut Alo Liliweri (Liliweri, 2009) adalah komunikasi antara anggota etnik maupun ras yang berbeda, atau juga komunikasi antara anggota etnik ataupun ras yang sama, tetapi dilatarbelakangi kebudayaan atau subkultur yang berbeda.

Dilansir dari halaman Detik.com Indonesia merupakan negara yang terdiri atas banyak etnis, terdapat 714 etnis yang tersebar luas di berbagai penjuru. Apalagi dengan perpindahan penduduk yang semakin pesat membuat etnis satu dengan yang lainnya menjadi berbaur antara satu dengan yang lain dalam lingkungan yang sama. Oleh karena itu terdapat banyak pasangan suami istri yang menikah dengan latar belakang etnis yang berbeda karena dipertemukan pada lingkungan yang sama. Pernikahan bukan hanya menyatukan dua orang yang berbeda menjadi sebuah keluarga, namun keluarga masing-masing pun akan terikat dalam hubungan keluarga. Oleh sebab itu ketika seseorang menikahi pasangannya, maka keluarga pasangannya akan menjadi keluarganya juga.

Komunikasi dibutuhkan untuk membangun hubungan keluarga antara menantu dan mertua, dalam fenomena pernikahan beda etnis, maka diperlukan komunikasi intrapersonal antarbudaya. Komunikasi antarbudaya memiliki hambatan karena adanya perbedaan latar belakang, norma, nilai, kepercayaan, dan bahasa. Di Kupang 
Nusa Tenggara Timur terjadi kasus pembunuhan yang menewaskan seorang wanita berinisial GK (25 tahun). Wanita tersebut dibunuh oleh mertuanya sendiri lantaran sang mertua kecewa pada menantunya karena telah menelantarkan cucunya (sumber: https://www.tribunnews.com/regional/2019/06/24/mertua-bunuh-menantunyakarena-kecewa-anak-dan-cucunya-ditelantarkan).

Everett Rogers dan Lawrence Kincaid (Liliweri, 2009) mengatakan jika komunikasi yang efektif muncul karena mutual understanding atau komunikasi yang saling memahami dimana seseorang dapat memperkirakan bagaimana orang lain dapat member makna atau pesan yang dikirim atau memberikan sandi balik atas pesan yang ia terima.

Teori yang penulis gunakan pada penelitian ini adalah teori model komunikasi menurut West dan Turner (2008) yaitu model linier, interaksional dan transaksional. Selain itu terdapat teori komunikasi antarbudaya mulai dari tahapan proses komunikasi antarbudaya, hambatan komunikasi antarbudaya dan juga yang teori komunikasi yang efektif. Peneliti mengambil penelitian H.H Daniel Tamburian (2015), Komunikasi Lintas Budaya Masyarakat Dayak Dalam Menjaga Kerukunan Hidup Umat Beragama sebagai referensi dan acuan dalam penelitian ini.

Berdasarkan pemaparan diatas, hal yang membuat penulis tertarik melakukan penelitian adalah pola komunikasi antara mertua dan menantu yang dilatar belakangi oleh perbedaan budaya dalam proses komunikasi antarpribadi. Oleh karena itu, penulis ingin mengangkat permasalahan ini menjadi bahan pembuatan penulisan ilmiah dengan judul "Pola komunikasi antarbudaya antara mertua dan menantu beda etnis".

\section{Rumusan Masalah}

Dalam komunikasi antarbudaya, ada proses komunikasi serta interaksi yang dilakukan oleh mertua dan menantu beda etnis ini. Komunikasi antarbudaya yang efektif akan membuat kedua pasangan mertua dan menantu ini memiliki hubungan keluarga yang baik. Berdasarkan paparan di atas, maka peneliti telah menarik rumusan masalah sebagai berikut:

A. Bagaimana pola komunikasi antarbudaya antara mertua dan menantu beda etnis?

B. Apa saja hambatan komunikasi antarbudaya dalam fenomena komunikasi antarbudaya mertua dan menantu beda etnis?

\section{Tujuan dan Manfaat Penelitian}

Secara khusus penelitian ini bertujuan untuk:

1) Mengetahui pola komunikasi antarbudaya antara mertua dan menantu beda etnis.

2) Untuk mengetahui apa saja hambatan pada proses komunikasi antarbudaya antara mertua dan menantu beda etnis.

Peneliti berharap dengan penelitian ini maka penelitian ini dapat memberikan manfaat untuk pihak-pihak yang membutuhkan. Adapun manfaat penelitian ini adalah:

\section{Manfaat Akademis}

Penelitian diharapkan mampu memberikan pengetahuan dan pemahaman mengenai komunikasi antarbudaya khususnya mengenai pola komunikasi intrapersonal antarbudaya. Penelitian juga bermanfaat bagi pembaca untuk menambah wawasan ataupun sumber terhadap penelitian lainnya pada masa mendatang. 


\section{Manfaat Praktis}

Peneliti berharap dengan penelitian ini, maka akan memberikan informasi dan manfaat bagi keluarga beda etnis mengenai pola komunikasi intrapersonal antarbudaya.

\section{Metode Penelitian}

Metode penelitian yang dipilih oleh penulis pada penelitian ini adalah metode kualitatif. Denzin dan Lincoln (Moleong, 2009) mengungkapkan penelitian kualitatif adalah penelitian dengan menggunakan latar alamiah, tujuannya untuk menafsirkan suatu fenomena yang terjadi serta dijalankan menggunakan metode yang ada. Menurut Strauss dan Corbin (Sujarweni, 2014), penelitian kualitatif merupakan jenis penelitian dimana dapat menghasilkan penemuan yang tidak dapat dicapai dengan menggunakan metode kuantifikasi (pengukuran). Sedangkan Jane Richie (Moleong, 2009: 6) mengungkapkan bahwa penelitian kualitatif merupakan sebuah upaya untuk menyajikan dunia sosial dan perspektifnya di dalam dunia, mulai dari persepsi, konsep, perilaku serta persoalan mengenai manusia yang diteliti.

Oleh karena itu penulis mengambil kesimpulan bahwa metode penelitian kualitatif adalah metode yang menghasilkan data deskriptif dan bertujuan untuk memahami objek yang diteliti. Penulis juga berusaha untuk menjabarkan bagaimana pola komunikasi dan masalah-masalah yang menjadi kendala dalam komunikasi antara mertua dan menantu beda etnis.

Pendekatan penelitian yang digunakan penulis adalah pendekatan deskriptif, yaitu sebuah penelitian dengan tujuan mendeskripsikan secara rinci mengenai fenomena sosial yang berkaitan dengan masalah yang diteliti penulis yaitu pola komunikasi antarbudaya mertua dan menantu beda etnis. Menurut Moh. Nazir (Nazir, 2009) penelitian deskriptif adalah sebuah metode penelitian yang meneliti status sekelompok individu, kondisi, suatu objek dan sebuah sistem pemikiran, ataupun sebuah kelas peristiwa yang terjadi sekarang dengan tujuan membuat gambaran atau deskripsi secara akurat, faktual dan sistematis perihal fakta juga sifat serta korelasi antar fenomena yang diteliti.

Penelitian deskriptif mempelajari masalah yang ada dalam masyarakat juga tata cara yang berlaku pada masyarakat serta situasi tertentu seperti mengenai hubungan, pandangan, kegiatan, sikap dan proses yang sedang berlangsung dan pengaruh dari fenomena tersebut.

\section{Hasil Penemuan dan Diskusi}

Menurut hasil wawancara penulis pola komunikasi yang terjalin oleh ketiga pasangan mertua dan menantu yang menjadi objek penelitian penulis memiliki pola yang serupa. Ketiga pasangan tersebut sama-sama menjadi pengirim sekaligus penerima pesan secara terus menerus, dengan komunikasi dua arah yang seperti ini dapat menghasilkan efektivitas komunikasi yang terjalin. Oleh karena itu hubungan ketiga pasangan tersebut semakin berkembang.

Berdasarkan wawancara yang dilakukan penulis kepada ketiga pasangan mertua dan menantu yang menjadi narasumber penulis, ketiga mertua tidak mempermasalahkan latar belakang etnis calon menantunya kala itu ketika sedang menjalin kasih bersama anaknya. Ketika ketiga pasangan tersebut ingin menikah, ketiga mertua tersebut menerima keputusan anaknya tanpa mengkhawatirkan latar 
belakang etnis sang calon menantu kala itu. Seiring berjalannya waktu komunikasi diantara ketiga pasangan mertua dan menantu tersebut makin akrab dan mulai menjalin hubungan yang baik bahkan setelah pernikahannya berlangsung. Walau terkadang terdapat sebuah konflik dan hal yang tidak disukai dari sang menantu, namun hal tersebut dapat diatasi dengan komunikasi yang terjalin.

Dua dari narasumber menantu yang diwawancarai penulis mengungkapkan bahwa mereka tidak khawatir ketika bertemu sang calon mertua kala itu, sedangkan satu narasumber menantu lainnya mengaku bahwa sebelum bertemu orangtua kekasihnya, ia mengaku sempat khawatir akan perbedaan etnisnya dengan keluarga sang kekasih. Namun setelah berjumpa langsung, ia merasa diterima dan perasaan khawatir tersebut mulai hilang. Sampai saat ini hubungan ketiga menantu tersebut berlangsung baik walau tak jarang ketiganya mengalami konflik dengan sang mertua.

\section{Simpulan}

Berdasarkan hasil penelitian yang telah dilakukan oleh penulis mengenai pola komunikasi antarbudaya di antara mertua dan menantu beda etnis, penulis dapat menarik kesimpulan sebagai berikut:

A. Penelitian yang dilakukan pada pasangan mertua dan menantu yang berbeda etnis dengan tujuan untuk mengetahui pola komunikasi antarbudaya yang dialami pasangan mertua dan menantu ini. Pola komunikasi terjalin pada tiga pasangan mertua dan menantu beda etnis adalah transaksional. Pesan yang disampaikan melalui proses yang panjang hingga dapat tersampaikan dan mendapatkan respon yang diinginkan juga memiliki pemahaman yang disetujui oleh pihak-pihak tersebut.

B. Komunikasi antarbudaya yang terjalin antara pasangan mertua dan menantu beda etnis tentunya bukan hal yang mudah mengingat perbedaan pola pikir, kebiasaan dan gaya komunikasi membuat keduanya sulit untuk membangun hubungan. Namun dengan adanya keterbukaan dan saling memahami maka komunikasi akan berjalan dengan baik. Terdapat banyak hambatan yang dapat mengganggu proses komunikasi antarbudaya yang terjalin antara ketiga pasangan mertua dan menantu yang berbeda etnis karena adanya perbedaan pola pikir, kebiasaan dan gaya komunikasi namun seiring berjalannya waktu terjadi pemahaman yang disetujui bersama.

\section{Ucapan Terima Kasih}

Penulis mengungkapkan rasa syukur pada Tuhan Yang Maha Esa atas segala berkat dan karunia-Nya sehingga peneliti dapat melaksanakan penelitian dan menyelesaikan penulisan jurnal ini. Penulis menyadari bahwa dukungan dan bimbingan dari berbagai pihak kepada penulis merupakan faktor yang mendukung dalam penyusunan laporan jurnal ini. Maka penulis ingin mengucapkan rasa terima kasih pada semua pihak yang telah membantu.

\section{Daftar Pustaka}

Budyatna, Muhammad \& Ganiem, Leila Mona. (2011). Teori Komunikasi Antarpribadi. Jakarta. Kencana. 
Liliweri, Alo. (2009). Makna Budaya Dalam Komunikasi Antar Budaya. Yogyakarta. LKiS Printing Cemerlang.

Moleong, Lexy J. (2017). Metodologi Penelitian Kualitatif. Bandung. Remaja Rosdakarya.

Nazir, Mohamad. (2011). Metode Penelitian. Bogor. Ghalia Indonesia.

Ridwan, Aang. (2016). Komunikasi Antarbudaya. Bandung. Pustaka Setia.

Rohim, Syaiful. (2016). Teori Komunikasi Perspektif, Ragam dan Aplikasi. Jakarta. Rineka Cipta.

Sujarweni, V. Wiratna. (2014). Metodology Penelitian. Yogyakarta. Pustaka Baru Press

Sanadi, Debora Ria. (2016). Komunikasi Interpersonal Pada Keluarga Beda Budaya. Universitas Semarang. (online). Terarsip di http://journals.usm.ac.id/index.php/the-messenger/article/view/165/137 25 Agustus 2019

Tamburian, Daniel. (2018). Komunikasi Lintas Budaya Masyarakat Dayak Dalam Menjaga Kerukunan Hidup Umat Beragama. Jurnal Komunikasi, Vol 10, No. 1. https://journal.untar.ac.id/index.php/komunikasi/article/view/1220 